\title{
Frequency of antiphospholipid antibodies in patients with infectious diseases using three different ELISA methods
}

\author{
Freqüência de anticorpos antifosfolipides em pacientes com doenças infecciosas usando \\ três diferentes testes de ELISA
}

Mittermayer Barreto Santiago ${ }^{1}$; Reinaldo Martinelli; Mitermayer G. Reis ${ }^{3}$; Eliana Almeida Reis ${ }^{3}$; Albert $\mathrm{Ko}^{3,4}$; Roberto Dias Fontes ${ }^{5}$; Moacir Paranhos Silva ${ }^{6}$; Eliane Goes Nascimento ${ }^{6}$; Ricardo Espinola7; Nigel Harris ${ }^{7}$; Azzudin Gharavi ${ }^{7}$; Silvia Pierangeli ${ }^{7}$

\begin{abstract}
key words abstract
Anticardiolipin antibodies

Objective: The standard enzyme-linked immunosorbent assay (ELISA) for anticardiolipin ( $\mathrm{aCL}$ ) antibodies is the most important test for the diagnosis of antiphospholipid syndrome (APS). However, the test is also positive

Antiphospholipid antibodies in some infectious diseases and other non-related syndromes. It has been suggested that the detection of antibodies to a mixture of phospholipids or to $\beta_{2}$-glycoprotein I ( $\beta_{2}$-GP I) has higher specificity for APS than the standard aCL ELISA. The aim of the present work is to compare the diagnostic specificity of three different antiphospholipid (aPL) assays in patients with infectious diseases. Methods: Antiphospholipid antibodies were searched by three ELISA techniques, namely standard $\mathrm{aCL}, \mathrm{APhL}{ }^{\circledR}$ ELISA kit and anti- $\beta 2-\mathrm{GPI}$, in sera of patients with infectious diseases, including syphilis (69), leptospirosis (33) and visceral leishmaniasis (30). Results: The frequency of positivity of IgG aPL in patients with syphilis, leptospirosis and Kala-azar was 13/69 (19\%), 9/33 (27\%) and 2/30 (6\%), respectively, using standard ELISA, versus only $1 / 69(1.4 \%), 0 / 33$ (0\%) and $0 / 30(0 \%)$ positivity by the $A P h L^{\circledR}$ ELISA kit. The positivity of the isotype IgM aPL was $10 / 69(14 \%)$, $4 / 33(12 \%)$ and $1 / 30(3 \%)$, respectively, by the standard ELISA, and $1 / 69(1.4 \%), 0 / 33(0 \%)$ and $0 / 30(0 \%)$ by the $A P h L^{\circledR}$ ELISA kit. The presence of significant levels of IgG anti- $\beta_{2}$ GPI was observed in $14 / 69$ cases of syphilis $(20 \%), 6 / 33$ cases of leptospirosis $(18 \%)$ and $16 / 30$ cases of Kala-azar $(53 \%)$. The APhL ${ }^{\circledR}$ ELISA kit had superior performance showing the highest specificity: $97 \%$ (95\% Cl: $92 \%-99 \%)$ for lgG compared to $81 \%$ (95\% Cl: 74\%-87\%) for standard ELISA and 72\% (95\% Cl: 64\%-79\%) for anti- $\beta_{2}$ GPI assay. Conclusions: The APhL ${ }^{\circledR}$ ELISA kit proved to be significantly more specific than the $\mathrm{aCL}$ standard ELISA and the anti- $\beta_{2} \mathrm{GPI}$ ELISA, and it should be used to help in the diagnosis and confirmation of APS.
\end{abstract}

resumo

Objetivo: O ensaio de enzyme-linked immunosorbent assay (ELISA) para a pesquisa de anticorpos anticardiolipina (aCL) é o mais importante teste para o diagnóstico da síndrome antifosfolipídica (SAF). Entretanto esse teste também pode ser positivo em algumas doenças infecciosas. Tem sido sugerido que a detecção de anticorpos para uma mistura de fosfolípides ou para $\beta_{2}$-glicoproteína I ( $\left.\beta_{2}-G P I\right)$ teria uma maior especificidade para a SAF que o teste de ELISA-padrão para aCL. O objetivo do presente estudo é comparar a especificidade de três testes para anticorpos antifosfolípides (aFL) em pacientes com doenças infecciosas. Métodos: Anticorpos antifosfolípides foram pesquisados por três técnicas de ELISA, ou seja, o teste-padrão para aCL, o kit de ELISA APhL ${ }^{\circledR}$ e o teste para anti-B2-GP I em pacientes com doenças infecciosas, tais como sífilis (69), leptospirose (33) e Calazar (30). Resultados: A freqüencia de positividade de aFL da classe IgG em pacientes com sífilis, leptospirose e Calazar foi de 13/69 (19\%), 9/33 (27\%) e 2/30 (6\%), respectivamente, com o ELISA-padrão para aCL versus $1 / 69(1,4 \%), 0 / 33(0 \%)$ e 0/30 (0\%) com o kit de ELISA APhL ${ }^{\circledR}$. A positividade do isotipo IgM foi de 10/69 (14\%), 4/33 (12\%) e 1/30 (3\%), respectivamente, com o ELISA-padrão para aCL, e 1/69 (1,4\%), 0/33 (0\%) e 0/30 (0\%) com o kit de ELISA APhL ${ }^{\circledR}$. Anticorpos da classe IgG contra $\beta_{2} G P I$ foram detectados em 14/69 casos de sífilis (20\%), 6/33 casos de leptospirose (18\%) e 16/30 casos de Calazar (53\%). Assim, o kit de ELISA APhL ${ }^{\circledR}$ apresentou uma maior especificidade: $97 \%$ (95\% Cl: 92\%-99\%) comparado com 81\% (95\% Cl: 74\%-87\%) para o teste de aCL-padrão e 72\% (95\% Cl: 64\%-79\%) para o teste de anticorpos anti- $\beta_{2}$ GPI. Conclusões: $O$ kit de ELISA APhL ${ }^{\circledR}$ parece ser mais específico para a SAF que o ELISA-padrão para aCL, assim como o teste para anti- $\beta_{2} G P I$. Esse kit pode ser usado para ajudar no diagnóstico e na confirmação da SAF. unitermos

Anticorpos anticardiolipina

Anticorpos antifosfolipides

Sindrome antifosfolipide

Doenças infecciosas

ELISA

1. Escola Bahiana de Medicina e Saúde Pública/Hospital Santa Izabel, Salvador, Bahia.

2. Faculdade de Medicina da Universidade Federal da Bahia (UFBA), Salvador.

3. Centro de Pesquisas Conçalo Muniz, Fundação Osvaldo Cruz, Salvador.

4. Weill Medical College, New York, NY.

5. Centro de Orientação e Apoio Sorológico (COAS) em doenças sexualmente transmissíveis (DST) da Secretaria de Saúde do Estado da Bahia (SESAB), Salvador.

6. Centro de Referência em Doenças Endêmicas Pirajá da Silva (PIE)/SESAB, Jequié.

7. Morehouse School of Medicine, Atlanta, GA, USA. 


\section{Introduction}

Anticardiolipin antibody $(\mathrm{aCL})$ tests are important to aid the physician in the diagnosis of antiphospholipid syndrome (APS) ${ }^{(21)}$. Patients affected with APS are subject to episodes of thrombosis in arteries and/or veins and pregnancy loss (probably secondary to thrombosis of vessels in the placenta), associated with antiphospholipid (aPL) antibodies. APL antibodies are autoantibodies directed against anionic phospholipids or protein-phospholipid complexes, measured by solid-phase immunoassays as $\mathrm{aCL}^{(10)}$ or as an activity that prolongs phospholipiddependent coagulation assays, the so-called lupus anticoagulant $(\mathrm{LA})^{(2)}$. Diagnosis of APS is based on finding a moderate to high positive aCL test and/or LA test with any one of the characteristic clinical features presented above. However, aCL enzyme-linked immunosorbent assay (ELISA) is not only positive in patients with APS, but also in a variety of disorders, including connective tissue diseases, infectious disorders, such as syphilis ${ }^{(4,18)}, \mathrm{Q}$ fever ${ }^{(9)}$, Lyme disease ${ }^{(16)}$, mycoplasma infection ${ }^{(6)}$, cytomegalovirus infection $^{(14)}$, tuberculosis ${ }^{(20)}$, Legionnaires' disease ${ }^{(7)}$, HIV $^{(5,13)}$, etc. Anticardiolipin antibodies present in infectious diseases are associated neither with clinical manifestations of APS nor with a positive lupus anticoagulant test. A false positive test for APS could lead to a dangerous misdiagnosis of patients and to unnecessary treatment.

Some investigators have suggested that the detection of antibodies to a mixture of phospholipid ${ }^{(17)}$ or to a cofactor $\beta 2$-glycoprotein I ( $\beta 2$-GP I) ${ }^{(3)}$ has higher specificity for APS than the standard anticardiolipin ELISA. However, some reports have recently indicated that anti-B2GPI antibodies can be found in patients infected by parvovirus B19(15) or HTLV-|(8), questioning the specificity of the anti- $\beta 2 \mathrm{GP}$ I test. The aim of the present work is to compare the diagnostic specificity of three different antiphospholipid ELISA assays in patients with infectious diseases.

\section{Material and methods}

\section{Patients}

Three groups of patients with infectious diseases were studied: a) sixty-nine patients with syphilis followed at the Sexually Transmitted Diseases Unit. The inclusion criterion was positivity for both venereal disease research laboratory (VDRL) and fluorescent treponemal antibody absorption (FTA-abs) tests in serum. The majority of the patients had already been treated with penicillin; b) thirty-three cases of leptospirosis whose diagnosis was based on clinical features and serologic tests; c) thirty patients with a diagnosis of visceral leishmaniasis (Kala-azar) before treatment. They came from an area in the northeast of Brazil in which this disease is endemic. The diagnosis was based on serologic tests and myelogram. None of the patients in the three groups had a history of thrombotic events or repeated spontaneous fetal losses. Patients signed an informed consent form approved by the Institution Review Board before participating in this study.

\section{Methods}

\section{Standard anticardiolipin assay}

The ELISA for anticardiolipin was performed as described elsewhere ${ }^{(10)}$ with some modifications: plates were coated overnight at $4^{\circ} \mathrm{C}$ with a $50 \mu \mathrm{g} / \mathrm{ml}$ solution of cardiolipin (Sigma) in ethanol. After evaporation of the solvent the wells were blocked with $10 \%$ adult bovine serum (ABS) in phosphate-buffered saline (PBS). The samples diluted in 10\% ABS (1:50) were added to wells in duplicate and incubated for two hours at room temperature. Alkaline phosphatase conjugated goat anti-human $\lg \mathrm{G}$ and $\lg \mathrm{M}$ (Sigma) was used as the second antibody. The reaction was developed as described above. International calibrators (Louisville APL Diagnostics, Doraville, GA) were used to construct a calibrator curve and to express the results in GPL and MPL units for $\lg G$ and $\operatorname{lgM} \mathrm{aCL}$, respectively. Degrees of positivity were considered as follows: high positive > 80GPL/MPL units, medium positive $\geq 20-80$ units, low positive $\geq 10,<20$ units.

\section{APhL $®$ ELISA kit}

We tested the samples for the presence of antiphospholipid antibodies (aPL) using the $A P h{ }^{\circledR}$ ELISA kit (Louisville APL Diagnostics, Inc., Louisville, KY, USA) and following the procedures suggested by the manufacturer. This kit characteristically utilizes a mixture of phospholipids instead of cardiolipin alone. The assay includes a set of six calibrators for IgG and IgM aPL and the results are expressed in GPL or MPL units for IgG or IgM, respectively. Cut-off for this assay is $15 \mathrm{GPL}$ or $15 \mathrm{MPL}$ units for $\lg \mathrm{G}$ or $\operatorname{lgM}$, respectively.

\section{$\beta 2$ GP I purification}

Human $\beta_{2}$ GP I was purified by perchloric acid treatment of normal serum followed by heparin-sepharose 
affinity purification as described previously ${ }^{(22)}$ with some modifications. Perchloric acid 70\% (1.25ml) was added drop by drop under constant stirring to $50 \mathrm{ml}$ of normal serum at $4^{\circ} \mathrm{C}$ and left stirring for 30 minutes. After centrifugation for $30 \mathrm{~min}$ at $10.000 \mathrm{~g}$, the supernatant was neutralized to $\mathrm{pH} 7$ and dialyzed overnight against $30 \mathrm{mM} \mathrm{NaCl}, 20 \mathrm{mM}$ Tris $\mathrm{HCl}$ $(\mathrm{pH}$ 7.2) with two changes of buffer. This preparation was passed through two columns of affinity chromatography: the contaminating IgG were removed first with protein $G$ (Pharmacia-Biotech) and then $\beta 2$ GP I was bound to a Heparin-Sepharose CL-6B (Pharmacia-Biotech) column. Then heparin-sepharose column was washed with increasing molarity of $\mathrm{NaCl}(30-150 \mathrm{mM}), 20 \mathrm{mM}$ Tris pH 7.2. $\beta 2 \mathrm{GPI}$ was eluted with $\mathrm{NaCl} 350 \mathrm{mM}$, Tris $20 \mathrm{mM}$ pH 7.2. All previous steps were carried out at $4^{\circ} \mathrm{C}$. Fractions with the highest optical density were collected and, after concentration with polyethylene glycol (PEG), were analyzed by sodium dodecyl sulfate polyacrylamide gel electrophoresis (SDS-PAGE) and immunoblotting using rabbit anti-serum to $\beta 2 \mathrm{GP} \mathrm{I}^{(11)}$.

\section{Anti- $\beta 2$ GP I assay}

This assay was performed as described previously by Roubey et al. ${ }^{(19)}$, with some modifications. The best antigen concentration for coating the plates, as well as the conjugate concentration, was determined before performing the ELISA. Microtitration high binding plates (Costar 3590) were coated with 50 $\mu \mathrm{l} /$ well of $\beta 2$ GP I in PBS $(10 \mu \mathrm{g} / \mathrm{ml})$ and left overnight at $4^{\circ} \mathrm{C}$. These plates, that are gamma-irradiated by the manufacturer, were used because they had been shown to be suitable for detecting the anti- $\beta 2$ GP I antibodies in sera from patients with APS in the absence of anionic phospholipid. The plates were blocked $(100 \mu \mathrm{l} /$ well) for one hour with $2 \%$ ovoalbumin (Sigma) in PBS. After washing with PBS the samples diluted $1: 100$ in $1 \%$ ovoalbumin $0.5 \%$ Tween 20 were added in duplicate $(50 \mu \mathrm{l})$ to the plate and incubated for two hours at room temperature. The alkaline phosphatase conjugated goat anti-human IgG (Sigma Aldrich, St Louis, Mo) diluted

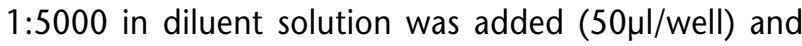
incubated for one hour. The reaction was developed using substrate $\mathrm{p}$-nitrophenyl phosphate diluted in diethanolamine buffer, and the optical density at $405 \mathrm{~nm}$ was read using a microplate reader (BioRad, Hercules $\mathrm{Ca}$ ). Furthermore, a positive control (patient with high aCL titer and APS) was used in each plate at three different dilutions: 1/100, 1/200 and $1 / 400$. The color reaction in each plate was stopped when the optical density (OD) of the 1/100 dilution of the positive control reached 1OD (this was approximately 15-20 min under the experimental conditions in which we run this assay).The results were considered positive when the OD obtained exceeded that of the mean value plus three standard deviations of 50 sera from normal healthy individuals. Different runs were normalized by using ten normal sera in each plate of anti- $\beta 2$ GP I ELISA. In order to express the results in units, the OD of each sample was subtracted from the cut-off and multiplied by 100 .

\section{Determination of specificity of an assay}

Specificity of a given assay was calculated as follows:

1 [(\# of non-APS samples that tested positive)/\# of samples tested] X 100

\section{Statistical analysis}

Quantitative variables were expressed as mean \pm standard deviation (SD). Difference of means was determined by Student's $t$ test. Pearson's coefficient of correlation was used whenever appropriate. Results were considered statistically significant when $p<0.05$.

\section{Results}

A total of 132 patients were included in the present study. Sixty-nine of them had the diagnosis of syphilis, 33 had leptospirosis and 30 had visceral leishmaniasis. The frequency of positivity of $\mathrm{IgG}$ aPL in patients with syphilis, leptospirosis and Kala-azar was 13/69 (19\%), 9/33 (27\%) and 2/30 (6\%), respectively, using standard ELISA versus only $1 / 69(1.4 \%), 0 / 33(0 \%)$ and $0 / 30(0 \%)$ positivity by the APhL ${ }^{\circledR}$ ELISA kit. The positivity of the isotype IgM aPL was $10 / 69(14 \%), 4 / 33(12 \%)$ and $1 / 30(3 \%)$, respectively, by the standard ELISA and 1/69 (1.4\%), 0/33 (0\%) and 0/30 (0\%) by the $A P h{ }^{\circledR}$ ELISA kit.

Analyzing the three groups of patients as a whole we found IgG aPL by the standard method in 24 out of 132 samples (18\%) and only four by the APhL ${ }^{\circledR}$ ELISA kit (3\%). Similarly, IgM aPL was found in 15 of the 132 samples (11\%) by the standard test, and only one patient was positive by the $A P h L{ }^{\circledR}$ ELISA kit. All patients with aPL by the APhL ${ }^{\circledR}$ ELISA kit were positive in standard ELISA. Of the 20 patients with $\lg \mathrm{aCL}$ by the standard test but negative by the $\mathrm{APhL}{ }^{\circledR}$ ELISA kit, eight had a low aCL value $(\geq 10,<20 \mathrm{GPL})$ and $12 \mathrm{had}$ a medium value ( $\geq 20, \leq 80 \mathrm{GPL}$ ). Of the $14 \mathrm{lgM}$ aCL positive by standard but negative by the $A P h{ }^{\circledR}$ ELISA kit, three had low level, ten had medium level and one had $133 \mathrm{MPL}$ units (high positive). Moreover, the mean titers of aPL detected by the $A P h L{ }^{\circledR}$ ELISA kit were lower than $\mathrm{aCL}$ by the standard ELISA $(p=0.01)$.

The presence of significant levels of IgG anti- $\beta 2$ GPI was observed in $14 / 69$ cases of syphilis (20\%), 6/33 cases of 
leptospirosis (18\%) and 16/30 cases of Kala-azar (53\%). There was no correlation between $\lg \mathrm{G}$ anti- $\beta 2 \mathrm{GPI}$ and $\operatorname{lgG}$ aPL either by standard $(r=0.030)$ or $\mathrm{APhL}^{\circledR}$ ELISA kit $(r=0.052)$.

The frequency of aPL antibodies using both standard ELISA and APhL ${ }^{\circledR}$ ELISA kit as well as anti- $\beta 2$ GPI in the three groups of patients is shown in Table 1. Since there was no patient with clinical features of APS we could calculate only the specificity of these methods. The APhL ${ }^{\circledR}$ ELISA kit had superior performance showing the highest specificity, 97\% (95\% Cl: 92\%-99\%) for IgG compared to 81\% (95\% Cl: $74 \%-87 \%)$ for standard ELISA and 72\% (95\% Cl: 64\%79\%) for anti- $\beta 2 \mathrm{GPI}$ assay (Table 2).

\section{Discussion}

The anticardiolipin ( $\mathrm{aCL}$ ) test is the most commonly used test to detect antiphospholipid antibodies and to help in the diagnosis of APS. This test, although sensitive, lacks specificity and detects antibodies in the sera of patients with a number of infectious diseases including syphilis, HIV, tuberculosis and others. ELISA tests that utilize a mixture of phospholipid instead of cardiolipin alone or $\beta 2$ glycoprotein I as antigen have been developed and these have been reported to be more specific for the diagnosis of APS ${ }^{(17)}$.

In the present study we confirmed the presence of aPL in patients with different infectious diseases, although without features of APS. Additionally, in accordance with previous reports ${ }^{(8,12)}$ we also found antibodies to cofactor $\beta 2-G P$ I in these patients. We also compared the diagnostic specificity of three different aPL ELISA methods and found a higher specificity of $\lg G A P h{ }^{\circledR}$ ELISA kit (97\%) than standard ELISA (81\%) or anti- $\beta 2$ GP I (72\%). This superiority in specificity of the $A P h L{ }^{\circledR}$ ELISA kit over the standard $\mathrm{aCL}$ ELISA has been previously demonstrated when a large group of patients with a variety of connective tissue diseases was studied $(99.5 \% \text { vs. } 96 \%)^{(17)}$. On the other hand, in that study the sensitivity of the APhL ${ }^{\circledR}$ ELISA kit for APS detection was excellent but lower than the standard ELISA to some extent, yielding a sensitivity of $90.9 \%$. Since no patient in the present series had APS, we could not compare the sensitivity of the assays.

Although we have no clear explanation for the better specificity of the APhL ${ }^{\circledR}$ ELISA kit, we can speculate that the mixture of negatively charged phospholipid used in that assay to coat the plates better mimics the physiological phospholipid composition seen in the cellular membrane (i.e. in endothelial cells and platelets). Alternatively, the superiority in specificity of the $A P h{ }^{\circledR}$ ELISA kit over the anti- $\beta 2$ GP I ELISA may rely on methodological explanations, since the prevalence of anti- $\beta 2$ GP I in different clinical situations may vary depending on the method of purification of that cofactor, the type of plastic plate utilized, and the ELISA procedure.

Table 1

Frequency of IgG and IgM aPL antibodies by the standard BLISA, APhL ELISA kit and IgG anti-

\begin{tabular}{lccccccc} 
Table 1 & B2 GPI antibodies in patients with syphilis, leptospirosis and Kala-azar \\
\hline \multicolumn{7}{c}{ ACL standard ELISA } & \multicolumn{3}{c}{ APhL' ELISA kit } & anti-ß2 GPI \\
Syphilis (69) & IgG & IgM & IgG or IgM & IgG & IgM & IgG or IgM & IgG \\
Leptospirosis (33) & $13(19 \%)$ & $10(14 \%)$ & $14(21 \%)$ & $1(1.4 \%)$ & $1(1.4 \%)$ & $1(1.4 \%)$ & $14(20 \%)$ \\
Kala-azar (30) & $2(6 \%)$ & $4(12 \%)$ & $11(33 \%)$ & $3(9 \%)$ & $0(0 \%)$ & $3(9 \%)$ & $6(18 \%)$ \\
\hline
\end{tabular}

Table 2

ACL standard ELISA

APhL' ELISA kit

Anti-ß2 GPI ELISA

\section{Specificity of three different antiphospholipid antibodies in ELISA methods}

$\begin{array}{lll}\text { IgG } & \text { IgM } & \text { IgG or IgM } \\ 81 \% & 88 \% & 79 \% \\ 95 \% \text { CI }(74 \%-87 \%) & 95 \% \text { CI }(82 \%-93 \%) & 95 \% \text { CI }(72 \%-85 \%) \\ \text { IgG } & \text { IgM } & \text { IgG or IgM } \\ 97 \% & 99 \% & 97 \% \\ 95 \% \text { CI }(92 \%-99 \%) & 95 \% \text { CI (96\%-99\%) } & 95 \% \text { CI }(92 \%-99 \%) \\ \text { IgG } & & \\ 72 \% & & \\ 95 \% \text { CI }(64 \%-79 \%) & & \end{array}$


A recent study comparing different kits in the detection of anticardiolipin and anti- $\beta 2$ GP I antibodies showed a high degree of variability in the results, putting in question testing of sera by one or several kits ${ }^{(1)}$. However, the APhL ${ }^{\circledR}$ ELISA kit was not included in that study.

In conclusion, the APhL ${ }^{\circledR}$ ELISA kit showed better specificity than the $\mathrm{aCL}$ and the anti- $\beta 2$ GP I ELISA. The utilization of a technique that provides a lower rate of false positive results can be important in avoiding misdiagnosis and mistreatment of patients who actually have no APS.
Hence, the $A P h{ }^{\circledast}$ ELISA kit is a useful tool in the diagnosis of APS and definitely proved to be excellent in the laboratory confirmation of APS.

\section{Acknowledgements}

Support for this project was provided by Conselho Nacional de Desenvolvimento Científico e Tecnológico (CNPq), Fundação Oswaldo Cruz/Ministério da Saúde and the National Institutes of Health, USA.

\section{Referências}

I.AUDRAIN, M.A. et al. Comparison of different kits in the detection of autoantibodies to cardiolipin and beta 2-glycoprotein I. Rheumatology (Oxford), v. 43, p. I 81-5, 2004.

2. BOEY, M. L. et al. Thrombosis in systemic lupus erythematosus: striking association with the presence of circulating lupus anticoagulant. Br Med J (Clin Res Ed), v. 287, p. I 02 I-3, 1983.

3. CABIEDES, J.; CABRAL, A. R.; ALARCON-SEGOVIA, D. Clinical manifestations of the antiphospholipid syndrome in patients with systemic lupus erythematosus associate more strongly with anti-beta 2-glycoprotein I than with antiphospholipid antibodies. / Rheumatol, v. 22, p. 1899-906, 1995.

4. CAMPBELL,A. L. et al. Comparison of the effects of anticardiolipin antibodies from patients with the antiphospholipid syndrome and with syphilis on platelet activation and aggregation. Thromb Haemost, v. 73, p. 529-34, 1995.

5. CANOSO, R. T.; ZON, L. I.; GROOPMAN, J. E. Anticardiolipin antibodies associated with HTLV-III infection. Br J Haematol, v. 65, p. 495-8, 1987.

6. CATTEAU, B. et al. Mycoplasma infection with Stevens-Johnson syndrome and antiphospholipid antibodies: apropos of 2 cases. Rev Med Interne, v. 16 p. 10-4, 1995.

7. DURUPT, S. et al. Presence of antiphospholipid antibodies in Legionnaires' disease. Presse Med, v. 25, p. I 649, 1996.

8. FAGHIRI, Z. et al. Antibodies to cardiolipin and beta 2 glycoprotein-I in HTLV-I-associated myelopathy/tropical spastic paraparesis. Lupus, v. 8, p. 210-4, 1999.

9. GALVEZ, J. et al. Thrombophlebitis in a patient with acute $Q$ fever and anticardiolipin antibodies. Med Clin (Barc), v. 108 , p. 396-7, 1997.

10. GHARAVI, A. E. et al. Anticardiolipin antibodies: isotype distribution and phospholipid specificity. Ann Rheum Dis, v. 46, p. I-6, 1987.

I I. GHARAVI,A. E. et al. Induction of antiphospholipid autoantibodies by immunization with beta 2-glycoprotein I (apolipoprotein H). J Clin Invest, v. 90, p. I I05-9, 1992.
12. GUERIN, V.; RYMAN, A.; COUCHOURON, A. Transitory antibeta 2-glycoprotein I antibodies in infections. Lupus, v. 8, p. 490- I, 1999

13. INTRATOR, L. et al. Anticardiolipin antibodies in HIV-infected patients with or without immune thrombocytopenic purpura. Br J Haematol, v. 68, p. 269-70, 1988.

14. LABARCA, J. A. et al. Antiphospholipid syndrome associated with cytomegalovirus infection: case report and review. Clin Infect Dis, v. 24 p. 197-200, 1997.

15. LOIZOU, S. et al. Similarities of specificity and cofactor dependence in serum antiphospholipid antibodies from patients with human parvovirus B 19 infection and from those with systemic lupus erythematosus. Arthritis Rheum, v. 40, p. 103-8, 1997

16. MACKWORTH-YOUNG, C. G. et al. Anticardiolipin antibodies in Lyme disease. Arthr Rheum, v. 31, p. 1052-6, 1988.

17. MERKEL, P. A. et al. Comparison between the standard anticardiolipin antibody test and a new phospholipid test in patients with connective tissue diseases. J Rheumatol, v. 26, p. 59|-6, 1999.

I 8. MOURITSEN, S. et al. The specificity of anti-cardiolipin antibodies from syphilis patients and from patients with systemic lupus erythematosus. Clin Exp Immunol, v. 76, p. 178-83, 1989.

19. ROUBEY, R. A. et al. "Anticardiolipin" autoantibodies recognize beta 2-glycoprotein I in the absence of phospholipid. Importance of $\mathrm{Ag}$ density and bivalent binding. I Immunol, v. I54, p. 954-60, 1995.

20.SANTIAGO,M. B. et al. Anticardiolipin antibodies in patients with infectious diseases. Clin Rheumatol, v. 8 p. 23-8, 1989.

21. WILSON, W.A. et al. International consensus statement on preliminary classification criteria for definite antiphospholipid syndrome. Arthritis Rheum, v. 42, p. I 309-1311, 1999.

22.WURM, H. Beta 2-glycoprotein-I (apolipoprotein $\mathrm{H}$ ) interactions with phospholipid vesicles. Int J Biochem, v. 16, p. 51 I-5 1984.

\section{Mailing address}

Mittermayer Barreto Santiago

Núcleo de Reumatologia do Hospital Santa lzabel

Praça Almeida Couto, 500, Nazaré

40.000-000 - Salvador-BA

Tel: (071) 33265276

Fax: (071) 3506221

e-mail: mitter@svn.com.br 